\title{
HPLC Analysis of Flavonoids in Eupatorium littorale
}

\author{
Brás H. de Oliveira ${ }^{a}{ }_{*}$,Tomoe Nakashima ${ }^{b}$, José D. de Souza Filho ${ }^{c}$ and Fabiano L. Frehse ${ }^{a}$ \\ a Departamento de Química, Universidade Federal do Paraná, C. P. 19081, 81531-970, Curitiba-PR, Brazil \\ ${ }^{\mathrm{b}}$ Departamento de Farmácia, Universidade Federal do Paraná, Curitiba - PR, Brazil \\ ${ }^{\mathrm{c}}$ Departamento de Química, Universidade Federal de Minas Gerais, Belo Horizonte - MG, Brazil
}

\begin{abstract}
Neste trabalho são descritos o isolamento e a identificação de eupafolina e hispidulina das folhas secas de Eupatorium littorale (Asteraceae). Foi desenvolvido também um método para a detecção desses flavonóides e de rutina na planta, utilizando a técnica de CLAE em fase reversa com detetor de arranjo de fotodiodos. Eupafolina e hispidulina foram quantificados sendo encontradas as concentrações de $0,29 \%$ e $0,21 \%$, respectivamente.
\end{abstract}

The isolation and identification of eupafolin and hispidulin in the dried leaves of Eupatorium littorale (Asteraceae) are described. A method for the detection of those flavonoids and rutin was also developed using reversed-phase HPLC with a photodiode array detector. Eupafolin and hispidulin were quantified and the concentrations found were $0.29 \%$ and $0.21 \%$, respectively.

Keywords: HPLC, flavonoids, Eupatorium, Asteraceae

\section{Introduction}

Eupatorium littorale is a shrub of up to $1 \mathrm{~m}$ high from the Asteraceae family. It is common in many parts of Brazil and very little is known about its chemistry. The only report found ${ }^{1}$ described the presence of quercetine (1) and rutin (2) in the plant leaves. Those compounds were detected by comparison with standards, using TLC.

HPLC is gaining increasing importance for the analysis of plant extracts. The qualitative analysis which produces a "fingerprint" chromatogram obtained under standard conditions, can be very useful for quality control of phytochemicals. Although TLC is a powerful and simple technique used for this purpose, there are situations in which it can produce doubtful results. HPLC can also be a useful tool in chemosystematics helping, for example, to characterize species on the basis of their secondary metabolite contents.

Reversed-phase HPLC has been used in a number of occasions for the analysis of flavonoids in plants. In one study ${ }^{2}$ it was used to distinguish species based on the quantitative variation of flavonoids among them. In another study ${ }^{3}$ it was used for the quantitative analysis of flavonoid aglycones. A comparison of reversed-phase columns has also been made 4 showing considerable discrepancy in performance.

e-mail: bho@quimica.ufpr.br
The analysis of metabolites of Eupatorium plants by HPLC, however, is rare. The only report found ${ }^{5}$ describes the use of the technique for the screening of sesquiterpene lactones in a few species of that genus. We could not find any report on the analysis of flavonoids in the genus by HPLC.

E. littorale is not currently used in folk medicine, but preliminary bioactivity tests have shown interesting results. General pharmacological activity tests 6 in rats showed it was active on the central nervous system and on smooth muscle. Anti-cancer in vitro tests ${ }^{7}$ showed weak activity, but with a significant selectivity for leukemic cells.

Considering the reported presence of flavonoids in other plants of the same family and the biological activity of $E$. littorale, we decided to carry out the isolation and identification of compounds of that class in the plant. Those compounds could be involved in the biological activity of the plant. We also intended to develop an HPLC method for the detection and quantification of flavonoids eventually isolated and to confirm the presence of quercetin and rutin, as previously reported ${ }^{1}$.

\section{Experimental}

\section{Plant material and extract preparation}

The aerial parts of E. littorale were collected in Piraquara (Metropolitan Region of Curitiba-Brazil), in April 1997. It was identified by Prof. Olavo Guimarães, the curator of UFPR 
Herbarium, where a voucher specimen is deposited (\# UPCB 12.400). The leaves ( $1.00 \mathrm{~kg}$ ) were dried at $40^{\circ} \mathrm{C}$, powdered and extracted twice with methanol. The solvent was evaporated at reduced pressure producing the crude extract (142.57 g).

\section{Extract fractionation}

The crude extract was redissolved in methanol:water (60:40) and partitioned against hexane, chloroform, ethyl acetate and $n$-butanol. Four grams of the chloroform extract were submitted to vacuum liquid chromatography using 60.0 $\mathrm{g}$ of silica (Merck art \# 7744). Elution was made with chloroform, ethyl acetate/chloroform (20, 40, 60, $80 \%)$, ethyl acetate, methanol/ethyl acetate $(20,40,60,80 \%)$ and methanol and $100 \mathrm{~mL}$ fractions were collected. Fractions 46 (190 mg) were combined and refractionated in a "flash" column of silica. Elution with chloroform/ethyl acetate (85:15) produced two solids, identified as $\mathbf{3}$ and $\mathbf{4}$.

Eupafolin (3). 46 mg, mp 272-275 (1it. ${ }^{8}$ 271-273); UV $\lambda_{\text {max }} / \mathrm{nm}(\mathrm{MeOH}): 348,273.5 ;{ }^{1} \mathrm{H}$ NMR (200 MHz, $\left.\mathrm{CDCl}_{3}+\mathrm{DMSO}_{6}\right) \delta 3.8(\mathrm{~s}, 3 \mathrm{H} ; 4$ '-OMe), $6.6(\mathrm{~s}, 1 \mathrm{H} ; \mathrm{H}-$ 3), 6.7 (s, 1H; H-8), 6.9 (d, J 8.9 Hz, 1H; H-5'), 7.4 (brd, J $8.9 \mathrm{~Hz}, 2 \mathrm{H}$; H-2', 6'), 13.1 (s, 1H; 5-OH); ${ }^{13} \mathrm{C}$ NMR $\left(50.3 \mathrm{MHz}, \mathrm{CDCl}_{3}+\mathrm{DMSO}_{6}\right) \delta 59.93(\mathrm{OMe}), 94.11$ (C-8), 102.40 (C-3), 104.07 (C-10), 113.36 (C-2'), 116.03 (C-5'), 118.96 (C-6'), 121.57 (C-1'), 131.33 (C-6), 145.73 (C-3'), 149.67 (C-4'), 152.35 (C-9), 152.80 (C-5), 157.23 (C-7), 163.95 (C-2), 182.02 (C-4).

Hispidulin (4). 5 mg, mp 289-291 (lit. $\left.{ }^{8} 288-289\right) ; \mathrm{UV} \lambda_{\max }{ }^{\prime}$ nm (MeOH): 336, 275; ${ }^{1} \mathrm{H}$ NMR (200 MHz, CDCl 3 +DMSO$\left.\mathrm{d}_{6}\right) \delta 3.9\left(\mathrm{~s}, 3 \mathrm{H} ; 4^{\prime}-\mathrm{OMe}\right), 6.6(\mathrm{~s}, 1 \mathrm{H} ; \mathrm{H}-3), 6.7$ (s, 1H; H-8), 6.9 (d, J 8.7 Hz, 2H; H-3',5'), 7.9 (d, J 8.7 Hz, 2H; H-2',6'), 13.1 (s, 1H; 5-OH); ${ }^{13} \mathrm{C} \mathrm{NMR}$ (50.3 MHz, $\mathrm{CDCl}_{3}+\mathrm{d}_{6}$-DMSO) $\delta$ 59.92 (OMe), 94.21 (C-8), 102.35 (C-3), 104.07 (C-10), 115.94 (C-3'), 115.94 (C-5'), 121.20 (C-1'), 128.40 (C-2'), 128.40 (C-6'), 131.32 (C-6), 152.36 (C-9), 152.77 (C-5), 157.22 (C7), 161.15 (C-4'), 163.78 (C-2), 182.09 (C-4).<smiles>COc1c(O)cc2oc(-c3ccc(O)c(O)c3)c(O)c(=O)c2c1O</smiles>

$$
\begin{aligned}
& 1 \mathrm{R}=\mathrm{H} \text { (quercetin) } \\
& 2 \mathrm{R}=\text { rutinose (rutin) }
\end{aligned}
$$<smiles>COc1c(O)cc2oc(-c3ccc(O)c(O)c3)cc(=O)c2c1O</smiles>

(eupafolin)

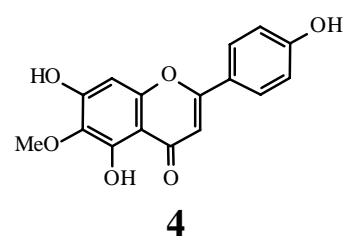

(hispidulin)
Scheme 1.

\section{Sample preparation for HPLC analysis}

$8.0 \mathrm{~g}$ of the powdered leaves were extracted in a Soxhlet with methanol $(150 \mathrm{~mL})$. At one hour intervals, aliquots were removed and checked for the presence of eupafolin and hispidulin by TLC. After $5 \mathrm{~h}$ the extract was absent of the target flavonoids. The extraction procedure was executed in triplicate, for $5 \mathrm{~h}$.

Each extract was then filtered and the volume was completed to $200 \mathrm{~mL}$ with methanol. An aliquot $(5 \mathrm{~mL})$ was filtered through a small column of C18 silica (55-105 $\mathrm{mm}, 0.50 \mathrm{~g}$ ) and the column eluted with $4 \mathrm{~mL}$ of methanol. The volume of the eluate was completed to $10 \mathrm{~mL}$. More 5 $\mathrm{mL}$ of methanol was applied to the column and the eluate was checked for the target flavonoids, which were absent.

\section{HPLC analysis}

The HPLC system (Varian) consisted of a pump (9012Q), a diode array detector (9065) and a Rainin autosampler (AI200). The system was controlled by Star Workstation. Column was a Dynamax C18, 250 x 4.6 mm, $5 \mu \mathrm{m}$ particle size (Rainin art. \# R0083201C). Methanol was from Merck (Art. MX0488-1). Water was HPLC grade and acidified to $\mathrm{pH} 3.0$ with phosphoric acid. Eupafolin and hispidulin were isolated from the same plant and characterized by spectroscopic methods. Rutin and quercetin were purchased from Merck.

Qualitative analysis was made with one of the samples, in step gradient mode, with methanol/water 1:1 (0-10 min) and 7:3 (10-20 $\mathrm{min})$ at a flow-rate of $1 \mathrm{~mL} \mathrm{~min}-1$. The injection volume was $30 \mu \mathrm{L}$ and the eluate was monitored at $339 \mathrm{~nm}$. The filtered methanolic extract was injected under these conditions (Figure 1) as well as a mixture of authentic samples of rutin, quercetin, eupafolin and hispidulin (Figure 2). The purity of each identified peak in Figure 1 was determined by comparison of the UVspectra at upslope and downslope inflexion points.

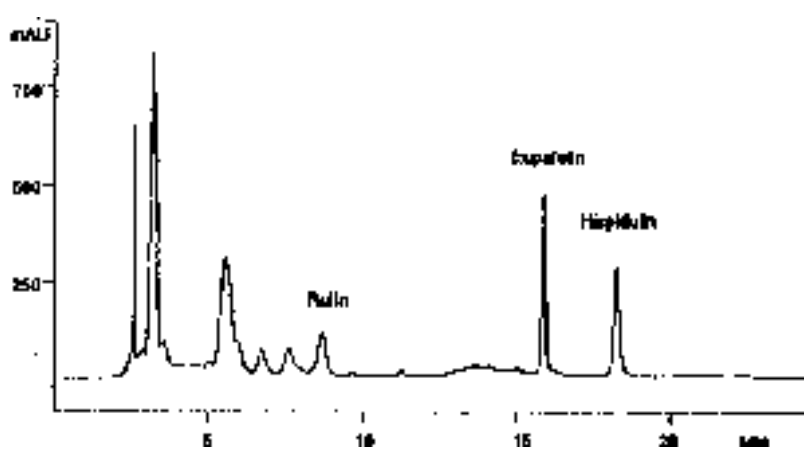

Figure 1. HPLC Fingerprinting of Methanolic Extract of E. littorale. Column: Dynamax C18 (250 x $4.6 \mathrm{~mm}, 5 \mu \mathrm{m})$; eluent: methanol/water

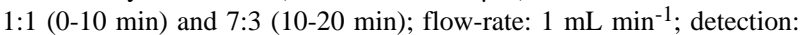
$339 \mathrm{~nm}$. 


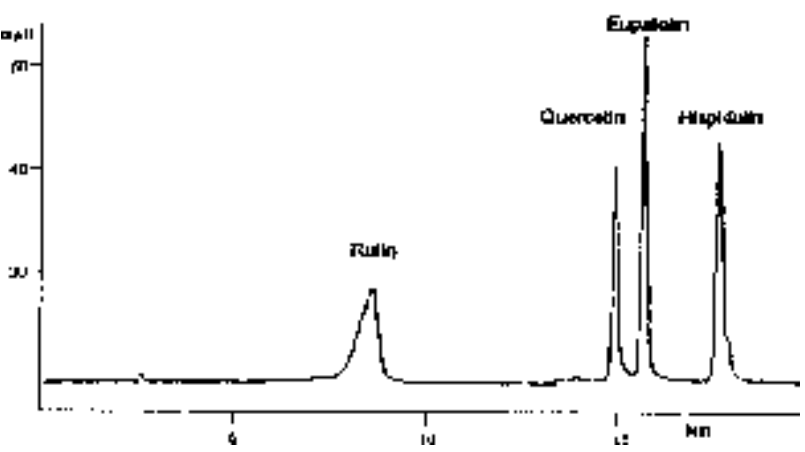

Figure 2. HPLC Chromatogram of authentic samples of Rutin, Quercetin, Eupafolium and Hispidulin. Conditions: same as for Figure 1.

Quantitative analysis was made with the three samples, in isocratic mode, with methanol/water (7:3) at a flow-rate of $1 \mathrm{~mL} \mathrm{~min}^{-1}$ and detection at $339 \mathrm{~nm}$ (Figure 3). External standard curves for authentic samples of eupafolin and hispidulin were prepared with 3 calibration solutions, with concentrations of 105.5, 211 and $264 \mathrm{mg} \mathrm{L}^{-1}$ for eupafolin and 89,178 and $222 \mathrm{mg} \mathrm{L}^{-1}$ for hispidulin. Each calibration solution was injected twice and the curves were constructed with the averages.

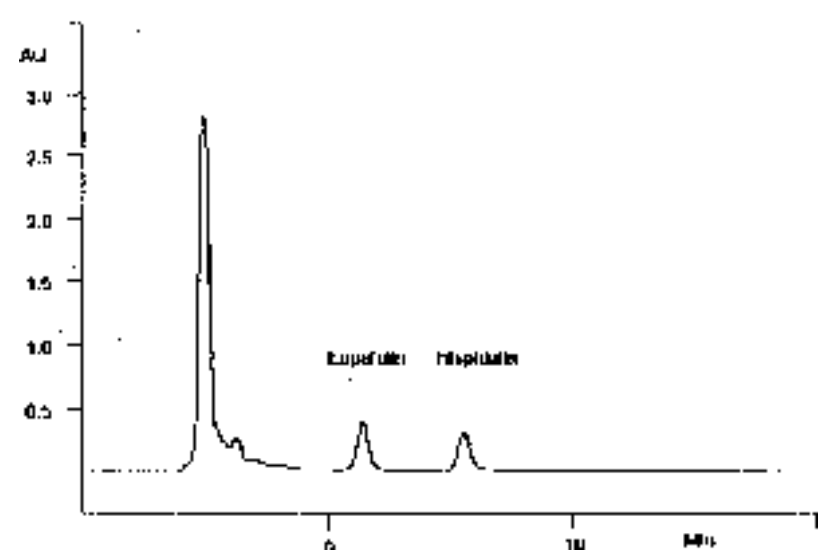

Figure 3. HPLC Chromatogram of the methanolic extract of E. littorale. Conditions: same as for Figure 1 except eluent (methanol/water 7:3).

\section{Results and Discussion}

The fractionation of the chloroform extract yielded two compounds. The flavonoidic nature of these compounds was apparent from their UV spectra, with $\lambda$ maxima at 348 and $273.5 \mathrm{~nm}$ for $\mathbf{3}$ and at 336 and $275 \mathrm{~nm}$ for $\mathbf{4}$. These maxima correspond to bands I and II, typical in this class of compounds. Analysis of the ${ }^{1} \mathrm{H}$ and ${ }^{13} \mathrm{C}$ NMR spectra of both compounds and comparison with literature data ${ }^{8,9}$ allowed us to characterize them as eupafolin (3) and hispidulin (4).

Compounds 3 and $\mathbf{4}$, described here for the first time in E. littorale, have been isolated from other Eupatorium plants. Eupafolin has been found, for example, in $E$. cuneifolium $^{8}$, E. cannabinum $^{10}$ and in E. subhastatum ${ }^{11}$ while hispidulin has been found in E. cannabinum ${ }^{8}, E$. cuneifolium $^{9}$, E. rotundifolium ${ }^{8}$, E. semiserratum $^{12}, E$. serratum $^{13}$ and E. subhastatum ${ }^{14}$.

Both compounds have important pharmacological properties. In an early study ${ }^{8}$ they showed significant cytotoxic action against $\mathrm{KB}$ cells. Anti-oxidant ${ }^{15}$ and antihepatotoxic ${ }^{16,17}$ properties have also been described for these compounds. Hispidulin itself has been found to have antibacterial ${ }^{18}$, antiedema ${ }^{19}$ as well as plant germination and root growth inhibition activities ${ }^{20}$. These properties led us to develop an HPLC method for the qualitative and quantitative analysis of those compounds in the plant.

\section{Qualitative analysis}

The method developed for HPLC fingerprinting provided a quick analysis of the methanolic extract. The conditions used led to a good separation of the peaks which could be identified in the chromatogram (Figure 1), as rutin ( $\mathrm{Rt}=9.2)$, eupafolin ( $\mathrm{Rt}=15.8)$ and hispidulin $(\mathrm{Rt}=18.2)$. They were identified by comparison with the chromatogram of the four reference compounds (Figure 2) obtained under the same conditions and the respective UV spectra, obtained on line. The three identified peaks in Figure 1 were considered to represent only one compound each because the UV spectra at the upslope and downslope inflection points, in each peak, were indistinguishable. The data were processed by the PolyView spectral processing software (Varian).

Quercetin, however, could not be detected, contrary to the result of a previous report ${ }^{1}$, which described the presence of that flavonoid in E. littorale by TLC. We found that quercetin $(\mathrm{Rt}=15.1)$ and eupafolin $(\mathrm{Rt}=15.8)$ have similar chromatographic behavior and, therefore it is likely that eupafolin was mistakenly identified as quercetin. This result illustrates the limitations of TLC for the qualitative analysis of plant extracts.

\section{Quantitative analysis}

The extraction time, using a Soxhlet extractor, was optimized by TLC analysis of the extract in the thimble in the last cycle of every 60 minutes interval. After $5 \mathrm{~h}$ the extract did not contain the flavonoids of interest, indicating the extraction was complete.

The sample clean up made by SPE C-18 microlumn and eluted with $4 \mathrm{~mL}$ of methanol was sufficient to quantitative recuperation of the target flavonoids, as was confirmed by absence of flavonoids in a second fraction of $5 \mathrm{~mL}$ of methanol. 
Table 1. Quantitative analysis of eupafolin and hispidulin in E. littorale methanolic extract.

\begin{tabular}{lccccc}
\hline Compound & $\begin{array}{c}\text { Retention } \\
\text { Time (min.) }\end{array}$ & k' & Calibration Function & $\begin{array}{c}\mathrm{R} \\
(\mathrm{mg} \%)\end{array}$ \\
\hline Eupafolin & 5.7 & 1.4 & $\mathrm{y}=8.030277 \mathrm{e}+3 \mathrm{x}-1.446086 \mathrm{e}+4$ & 0.9998 & $288.0 \pm 3.1$ \\
Hispidulin & 7.7 & 2.2 & $\mathrm{y}=8.980118 \mathrm{e}+3 \mathrm{x}-2.414479 \mathrm{e}+4$ & 0.9997 & $213.1 \pm 6.5$ \\
\hline
\end{tabular}

$\mathrm{y}=$ area units, $\mathrm{x}=$ concentration in standard solution $\left(\mathrm{mg} \mathrm{L}^{-1}\right)$

The analysis time is an important factor in analytical work and the run time should be reduced to a minimum in order to optimize equipment use and reduce solvent consumption. Although the peaks of eupafolin and hispidulin were well resolved under the conditions used for the fingerprinting chromatogram (Figure 1), when we increased the organic modifier content of the mobile phase the peaks of interest were still well resolved but with reduced retention time (Figures 2 and 3). With $70 \%$ methanol and in isocratic mode, the run time could be as short as $10 \mathrm{~min}$.

The calibration curves showed linearity in the concentration range used for the standards. The standard solutions were injected in duplicate and the resulting curves had a very good linear correlation coefficient $(R)$. The detection limits, based on three times the noise level, were $12.2 \mathrm{ng}$ for eupafolin and $12.9 \mathrm{ng}$ for hispidulin. The results of the quantitative analysis are the average of three samples and the data are summarized in Table 1 . The variation coefficients were $1 \%$ for eupafolin and $3 \%$ for hispidulin, showing that the sample extraction and preparation were reproducible.

The results above showed, therefore, that E. littorale is a rich source of the important biologically active flavonoids, eupafolin and hispidulin, described here for the first time, in the plant. The described HPLC procedure could be useful for the qualitative and quantitative analysis of flavonoids in plant materials, especially those of the Asteraceae family. It can also be used in the quality control of phytopreparations containing rutin, quercetin, eupafolin and hispidulin as well as in chemosystematics.

\section{Acknowledgements}

We thank FINEP for financial support and CNPq for a scholarship to F.L.F. We are also thankful to LAREMAR, UFMG, for the NMR spectra.

\section{References}

1. Sato, M. E. M.Sc. Thesis, Universidade Federal do Paraná, 1985.
2. Harborne, J. B.; Boardley, M.; Linder, H. P. Phytochemistry 1985, 24, 273.

3. Hertog, M. G. L.; Hollman, P. C. H.; Venema, D. P. J. Agric. Food Chem. 1992, 40, 1591.

4. Crozier, A.; Jensen, E.; Lean, M. E. J.; McDonald, M. S. J. Chromatography A 1997, 761, 315.

5. Bos, R.; Woerdenbag, H. J.; Drenth, B. F. H. Planta Med. 1986, 532.

6. Hansaul, A. C. Estudos Preliminares dos Efeitos Farmacológicos do Extrato Bruto Hidroalcoólico da Eupatorium littorale Cabrera. Specialization Monography, Universidade Federal do Paraná, Curitiba, 1999.

7. Preliminary personal report. National Cancer Institute (USA), 2000.

8. Kupchan, S. M.; Sigel, C. W.; Hemingway, R. J.; Knox, J. R.; Udayamurthy, M. S. Tetrahedron 1969, 25, 1603.

9. Fernandez, I.; Garcia, B.; Grancha, F. J.; Pedro, J. R. Phytochemistry 1989, 28, 2405.

10. Elema, E. T.; Schripsema, J.; Malingre, T. M. Pharm. Weekbl. (Sci. Ed.) 1989, 115, 161.

11. Ferraro, G. E.; Coussio, J. D. Phytochemistry 1973, 12, 1825.

12. Herz, E.; Govidan, S. V.; Kumar, N. Phytochemistry 1981, 20, 1343.

13. Herz, W.; de Groote, R.; Murari, R.; Kumar, N.; Blount, J. F. J. Org. Chem. 1979, 44, 2784.

14. Ferraro, G.; Martino, V.; Borrajo, G.; Coussio, J. D. Phytochemistry 1987, 26, 3092.

15. Sanz, J. J.; Ferrandiz, M. L.; Cejudo, M.; Terencio, M.C.; Gil, B.; Bustos, G.; Ubeda, A.; Gunasegaran, R.; Alcaraz, M. J. Xenobiotica 1994, 24, 689.

16. Oshima,Y.; Kawakami,Y.; Kiso,Y.; Hikino, H.; Yang, L.; Yen, K. Jap. J. Pharmacol. 1984, 382, 201.

17. Ferrandiz, M. L.; Bustos, G.; Paya, M.; Gunasegaran, R.; Alcaraz, M. J. Life Sci. 1994, 558, 145.

18. Backhouse, N.; Bravo, B.; Erazo, S.; Garcia, R.; Avendano, S. Plant Med. Phytother. 1987, 212, 168.

19. Gil, B.; Sanz, M. J.; Terencio, M. C.; Ferrandiz, M. L.; Bustos, G.; Paya, M.: Gunasegaran, R.; Alcaraz, M. J. Life Sci. 1994, 5420, 333.

20. Baruah, N. C.; Sarma, J. C.; Barua, N. C.; Sarma, S.; Sharma, R. P. Phytochemistry 1994, 361, 29.

Received: December 14, 2000 Published on the web: April 9, 2001 